\title{
ACCESS TO FAMILY PLANNING SERVICES AMONG POOR COUPLES OF CHILDBEARING AGE IN YOGYAKARTA
}

\author{
Ratu Matahari'), Fitriana Putri Utami'1), Sri Sugiharti²) \\ 1)Department of Reproductive Health, Faculty of Public Health, Universitas Ahmad Dahlan \\ 2)National Population and Family Planning Board, Yogyakarta
}

\begin{abstract}
Background: Couples of childbearing age (PUS) in poorer regions contribute more to the high rate of unmet need, compared to couples who live in better areas. The very low utilization of free family planning can affect population growth and have an impact on other lives such as the economic and social sectors. This study aimed to investigate the access to family planning services among poor PUS in Yogyakarta.

Subjects and Method: This was a cross-sectional study conducted in Mergangsan, Umbulharjo, and Tegalrejo subdistrict in Yogyakarta. A total of 368 poor PUS aged 1549 years in was selected for this study. The data were collected by questionnaire. The data were analyzed by chi-square.

Results: $67.1 \%$ of poor PUS utilized contraceptive, of which $38.5 \%$ used IUD contraceptive. $94.6 \%$ of poor PUS had national health insurance coverage. $68.0 \%$ of poor PUS obtained family planning service from the community health center and $16.2 \%$ from midwife private clinic. $67.6 \%$ of poor PUS chose this facilities because it was near their house. Conclusion: Poor PUS obtain family planning service from the community health center and midwife private clinic. They choose this facilities because it is near their house.
\end{abstract}

Keywords: family planning, family planning access, poor couple

\section{Correspondence:}

Ratu Matahari. Department of Reproductive Health, Faculty of Public Health, Universitas Ahmad Dahlan, Yogyakarta. Email: ratu.matahari@ikm.uad.ac.id. Mobile:081228536118. 